\title{
Sánchez Rodríguez, V. (2020). La Comparsa Peñarandina. Historia y repertorio musical para la pervivencia de una tradición. Salamanca: Diputación de Salamanca, 196 pp. ISBN: 978-84-16419-31-9.
}

A pesar de que las nuevas tecnologías rodean nuestro día a día en el siglo XXI, nuestro existir también está determinado por las costumbres y tradiciones que se han ido gestando en los siglos previos. Pero, junto a las usanzas de lejano arraigo, existen otras manifestaciones culturales surgidas en las últimas décadas que han logrado convertirse en tradiciones gracias a su imbricación en la sociedad. A este respecto, la novedad editorial que aquí presentamos expone el estudio de uno de esos casos emplazado en la provincia de Salamanca, concretamente en la localidad de Peñaranda de Bracamonte.

En La Comparsa Peñarandina. Historia y repertorio musical para la pervivencia de una tradición se expone la historia de la mencionada agrupación musical y se recoge el cancionero interpretado por ésta, convertido ya en tradición en la localidad salmantina. La Comparsa Peñarandina es un grupo de aficionados que, desde los años ochenta, forma parte de la oferta cultural de la mencionada población, especialmente en fechas navideñas. Su particularidad es que recogen una tradición de canciones creadas por otras comparsas de la población durante las décadas de los años cincuenta y sesenta. A este respecto, la Comparsa Peñarandina, a través de sus actuaciones y de su implicación en el ritmo vital de la ciudad salmantina, ha logrado convertirse en un símbolo cultural pero también en convertir las canciones que interpretan en tradicionales.

La autora del volumen es Virginia Sánchez Rodríguez, Profesora Ayudante Doctoral de la Universidad de Castilla-La Mancha e investigadora del CIDoM-Unidad Asociada al CSIC. Doctora en Musicología por la Universidad de Salamanca (2013), junto a sus numerosas y ensalzadas investigaciones relativas a música de cine y a la relación entre música y mujer, también es especialista en música de carácter tradicional. De hecho, además de sus galardones, ha sido distinguida con la Beca de Investigación Etnográfica "Ángel Carril" del Instituto de las Identidades de la Diputación de Salamanca en la edición de 2016 y la reconocida Beca de Investigación en Folklore CIOFF-INAEM en el año 2018, con trabajos relativos tanto a manifestaciones musicales de Castilla y León como de Castilla-La Mancha.

En lo que respecta al volumen reseñado, se caracteriza por realizar un acercamiento a los cancioneros de toda la región en busca de vestigios musicales de Peñaranda de Bracamonte, por presentar un profundo estudio de carácter histórico-social de la localidad y por recoger, de forma documental, las melodías de las principales canciones interpretadas, durante décadas, por la Comparsa Peñarandina. De hecho, su principal aportación tiene que ver, precisamente, con que la doctora Sánchez Rodríguez ha realizado la transcripción 
de un elevado número de canciones interpretadas por la Comparsa Peñarandina, de modo que este repertorio, que no contaba con un soporte material hasta la fecha, no se pierda y que cualquier persona con ciertos conocimientos musicales sea capaz de dar vida a estas manifestaciones sonoras. Se trata, por tanto, de un encomiable trabajo de recuperación material de un vestigio inmaterial que permitirá la conservación futura de este repertorio, en riesgo de desaparición, como otras expresiones de carácter oral.

En cuanto a su estructura, el libro, de 196 páginas de extensión, comienza por una minuciosa introducción de carácter académico que es continuada por cuatro capítulos. Mientras el primero de ellos ("El fenómeno de las comparsas en Peñaranda de Bracamonte: contexto local y orígenes de un repertorio musical vigente en la actualidad") profundiza en la historia de agrupaciones de carácter amateur con incidencia en la sociedad, el segundo capítulo ("La Comparsa Peñarandina: recuperación y transmisión de una práctica musical convertida en tradición) presenta la configuración y el funcionamiento del grupo protagonista, la Comparsa Peñarandina. El tercer capítulo es el más original ("El Cancionero de la Comparsa Peñarandina") por acoger la transcripción musical y textual de 33 canciones. Dicha notación musical está realizada de forma exhaustiva y profesional, resultando, a su vez, de sencilla lectura. El cuarto capítulo ("Estudio del repertorio musical de la Comparsa Peñarandina: rasgos musicales y sociales”), por su parte, significa un interesante estudio de carácter musicológico y social sobre las canciones anteriormente expuestas, dando cuenta, a través de los análisis aportados, del profundo conocimiento del patrimonio musical de carácter oral de la región por parte de la autora y de que este volumen no es solo un compendio de melodías, sino un análisis de las mismas en distintas direcciones. Tras las conclusiones, se ofrece una profusa bibliografía final que hace referencia a los numerosos libros y artículos académicos referenciados a lo largo del trabajo.

Se trata de un volumen bien escrito y riguroso que, a pesar de su especificidad, resulta de amena lectura. Si bien es cierto que será especialmente de interés para los vecinos de la provincia de Salamanca y de la localidad referida, este libro puede convertirse, sin duda, en un referente como modelo de trabajo en la dignificación y transcripción de un repertorio arraigado desde la perspectiva social, pero también en relación con el reconocimiento que se ofrece a los protagonistas de nuestra intrahistoria cotidiana.

Javier Benito Blanco

Universidad de Castilla-La Mancha

ORCID iD: https://orcid.org/0000-0003-2576-6857 